\title{
Federal Inland Revenue Service Tax Awareness Index: Development and Validation
}

\author{
Fred Femi Akinfala ${ }^{1}$, Martha Ekong ${ }^{1}$, Abubakar, M. Liman ${ }^{1}$, Pirfa Tyem ${ }^{1}$, Adashu Ashu ${ }^{1} \&$ Mohammed \\ Kam-Selem ${ }^{1}$ \\ ${ }^{1}$ Federal Inland Revenue Service, Abuja, Nigeria \\ Correspondence: Fred Femi Akinfala, Federal Inland Revenue Service, Abuja, Nigeria. E-mail: \\ frederick.akinfala@firs.gov.ng
}

Received: April 23, 2018

doi:10.5539/ijbm.v13n7p249
Accepted: May 13, 2018

Online Published: June 15, 2018

URL: https://doi.org/10.5539/ijbm.v13n7p249

\begin{abstract}
Taxation is not just a means for generating revenue for the country, it is also a tool used to regulate the economy using fiscal policy, to control inflation, prices of goods and services and bridge the gap between the rich and the poor. However, the awareness for this all-important component of any goal-oriented government is poor. It is against this backdrop that this study aimed at developing a Tax Awareness Index for use in the Nigerian context. The study adopted descriptive survey approach with a cross-sectional design. The sampling approach to recruit participants for the study was the convenience sampling method. Data analysis involved the use of principal component analysis (PCA) with Varimax rotation. Results showed that the initially proposed 10-factor solution of 94 questionnaire items was not supported with the data gathered. However, a 5-factor solution emerged that made substantive sense for the purpose of developing a Tax. Awareness Index. A composite score on the 5-factor solution indicates the level of tax awareness for a respondent. It was concluded that this index would serve as a viable tool to measure how much the general populace is aware of tax and its components.
\end{abstract}

Keywords: Nigeria, tax, tax awareness, federal inland revenue service

\section{Introduction}

Tax is conceptualized as a compulsory contribution by tax payers regardless of any matching return of services or goods by the government (James \& Nobes, 2000). Tax or taxation does not occur in a vaccum. Governments levy and raise tax revenue to finance various public expenditures (Palil, 2010).

Taxation is a compulsory levy imposed by the government on its citizens on their profits, consumption and income while Tax awareness is basically how informed or how well people know and are familiar with the relevant taxes levied on them by the government and the impact of those taxes on their individual lives and the economy as a whole. Taxation is not just a means for generating revenue for the country, it is also a tool used to regulate the economy using fiscal policy, and with taxation, inflation can be controlled, prices of goods and services can be controlled and the gap between the rich and the poor can be bridged if proper tax awareness is created and enforced.

According to Steinmo (1996), Governments need money. Modern governments need lots of money. How they get this money and whom they take it from are the two most difficult political issues faced in any modern political economy. Tax awareness is key to tax compliance, when the citizens in a country are aware of their tax responsibilities they are more likely to remit their tax liabilities as and at when due to relevant tax authorities. Tax awareness has a positive and significant impact on taxpayer compliance (Santi 2012). When the level of tax compliance is high the level to the gross domestic product (GDP) ratio will be high and government would have more money to fund projects and effectively regulate and stir the economy in the right part. However, where compliance is low, sour taste is left in the mouth. Fowler (2018) argued that with the current state of the oil industry, huge infrastructure deficit and increasing external debt in the last eight years, it is now clear that reliance on oil is not sustainable with a tax to GDP ratio of only 6 per cent, one of the lowest in the world with Ghana at $15.9 \%$, most developed countries are at about $30 \%$. There is a lot of work to be done in creating awareness and bringing people into the tax system. Akinfala (2017) argued that tax revenue is a reliable and sustainable way of generating income for government to prosecute government business. Prosecuting government business is not just to pay salaries but more importantly, to provide public goods and services for all citizens, whether you are in employment of government or not, whether you are a paid employee or self-employed person. But the irony, however, 
is that the level of tax awareness is still poor across the country Adeosun (2017) This implies that since the product "tax" is not common and not everyone wants to buy it, a lot of people will feign ignorance and consequently choose to become "unaware" of its existence. One of the major functions of the tax authorities as spelt out in the recently released Tax Policy (2017) is "To promote tax awareness and a tax culture in Nigeria, the Federal and State tax authorities through the Joint Tax Board shall set aside a uniform day in the year as a National Tax Day".

Adeosun (2017) opined that many state governments get away with wastage and corruption because of non-compliance to tax payment by many Nigerians, especially at the state level. This could be explained by several factors. It could be due to lack of trust based on previous experiences where taxes are paid but not remitted to the government's coffers on one hand, or in the case where they are remitted but such fund is diverted for personal aggrandizement. These could explain for increased non-compliance. Furthermore, Adeosun (2017) submitted that governments at the state levels will become more responsible when Nigerians hold them accountable which is only possible when they pay their taxes, adding that such action is part of their duties. Officially, the number of taxpayers paying N10 million and above as tax per year, as at 2017, was 943. Of these, 941 were based in Lagos, with only two based in Ogun State. The implication of this is that in all the other states and the Federal Capital Territory, there is no billionaire or multi-millionaire. That may not be the case, given the assets scattered around the country and vehicles on our mostly decrepit roads. What it means is that many property owners in urban areas have not been paying tax or have been underpaying taxes.

Nigeria Bureau of Statistics estimated that Nigeria has a population of about 193,392,517 million people as at 2016. The economically active or working age population (15 - 64 years of age) was 111.1 million in Q3 2017 according to the National Bureau of Statistics (NBS). Furthermore, as released by the Joint Tax Board (JTB), only about 10 million people, out of this number, are registered for personal income tax across the 36 states and the Federal Capital Territory (FCT). These numbers just do not add up. How does one explain that 10 million people carry the tax burden that at least 77 million people are expected to share? This is 13 for the cost of 100 . There are four possible groups within the Nigerian tax bracket; enterprises (multinational and domestic), High Net worth Individuals (HNIs), the formally employed and the informally employed. According to Adefeko (2018),oil revenues still account for about 70 per cent of government income, a reality that leaves the economy very vulnerable to fluctuations in the oil market.

The above lends credence to the need for a reassessment of the government's current approach to improving the country's tax base through the Voluntary Assets and Income Declaration Scheme (VAIDS). VAIDS was introduced in 2017 to create awareness on the obligations of Nigerians as it pertains to tax payments, raise additional revenue of $\$ 1 \mathrm{bn}$ to reduce Nigeria's borrowing needs, allow investment in vital infrastructure, spur development, capture additional 4 million more tax payers in its net, increase Nigeria's tax to Gross Domestic Product (GDP) ratio from six per cent to 15 per cent by 2020, broaden the Federal and State tax brackets, curb non-compliance with existing tax laws and discourage use of tax havens and prevent illicit financial flows and reduce tax evasion in exchange for amnesty on criminal prosecution and penalties Osinbajo (2017). Nigeria declared every Thursday as "Tax Thursday", the scheme ends on $30^{\text {th }}$ June, 2018.

Before oil was discovered in Nigeria, most Nigerians paid their taxes, the decline in taxation as a key source of government revenue in Nigeria came about when Oil was discovered in Nigeria in 1956 by Shell-BP at Oloibiri in the Niger Delta area after half a century of exploration. The focus then changed from agricultural driven economy to an oil driven economy, less and less emphasis was placed on tax as a key source of government revenue because of the large revenue coming from the oil sector except for the very obvious taxes such as PAYE which is deducted at source, Company income tax especially for registered companies, Petroleum profit tax and VAT charged on consumption. The refocus on the Nigerian economy to oil not only lead to a decline in the level of tax awareness, and because the level of tax awareness is low, the revenue accruable to the government from tax payments is significantly reduced. This then has implication for the government's responsibilities to the citizen. The focus on a single product (oil) at the expense of others has also led to a fall in the level of trading activities in Nigeria, especially among small and medium scale enterprises (SMEs). Hence, businesses find it hard to cope as less emphasis was made to strengthen other sectors. This caused many businesses which needed government special support to go out of business and thus tax revenue which should have been collected from these businesses were lost.

This scenario has spread into different parts of the economy such as; the agricultural sector, mining sector, manufacturing sector, tourism sector etc. It also made it hard for infant indigenous industries to survive because the competition with imported goods was high and they sold at a lower price. High cost of production for manufacturing firms, especially SMEs causes them to either go out of business, lay off workers or reduce salaries to stay in business. All these factors and many more have their implications on the economy of Nigeria as a whole and specifically tax. Although this is a problem that need to be answered, there is a dearth of literature on tools that 
measures the level of tax awareness among expected tax payers. The objective of this study is to fill the knowledge gap in terms of the dearth of an appropriate instrument for measuring and predicting tax awareness and other variables affecting taxation. The development and validation of the tax awareness index (FIRS-TAI) is one of the bold attempt at remediating an aspect of the policy defect in view of the fact that tax awareness is one of the independent variables affecting tax compliance in Nigeria.

\section{Literature Review}

Tax is something undeniable for every citizen, their awareness of taxation will be important in pursuing tax compliance. Alstadsæter (2013) in his study on the effect of awareness and incentives on tax evasion found that tax awareness has an explanation as to why some taxpayers engage in legal tax avoidance activities while others do not. The taxpayer's awareness of tax rules depends on the salience of taxes. He concluded that lack of tax awareness and complexity of the tax code can result in accidental tax evasion through overstatement of the dividend allowance. Studies have shown that there exists a positively significant relationship between tax knowledge, tax awareness and tax compliance (Adekanola, 1997; Ola, 2001). These studies concluded that when people are adequately informed about taxes, there level of awareness increases and consequently their compliance level. However, Palil (2010) found that tax knowledge has a significant impact on tax compliance even though the level of tax knowledge varies significantly among respondents. The author opined that being informed about tax is not always a significant predictor of tax compliance in all cases and among different populations.

Contrary to Palil (2010), Berhane's (2011) study showed that tax compliance is influenced by tax education.

Third variables have also been implicated as mediators in tax compliance. For instance Savitri \& Musfialdy (2016) found that service quality has a full mediating role in relationship between taxpayers' awareness, tax penalties, and compliance cost and tax payer compliance. Mukhlis, Utomo, and Soesetio (2015) opined that tax education has a positive and significant impact on tax knowledge, tax knowledge has a positive effect on tax fairness, tax fairness has a significant positive effect on tax compliance and tax knowledge has a significant and positive effect on tax compliance. Furthermore, Hastuti (2014) in his study on tax awareness and tax education: a perception of potential taxpayer's results shows that there's no significant difference in contextual tax awareness between groups. It indicates that tax function and the obligation to do self-assessment are got into their head without considering whether they come from business or non-business program of study. It is also happened in a view of ethical tax awareness. This is to show to the government since tax awareness has already been generated among the youth. Rahayu et al (2017) found that knowledge and understanding of tax regulation in the society through the awareness of taxpayer do not have significant influence on tax compliance; a new understanding and a better perspective of the influence of knowledge, understanding, and awareness of taxpayer compliance.

Different factors might affect tax compliance attitude which would have been a fallout of low level of awareness. Such factors could include economical, institutional, social, individual factors. Previous empirical studies (Lemessa, 2007; Beza, 2014; Amina \& Saniya, 2015;) also found the following factors as determining factors for tax compliance (tax knowledge, perception on government spending; perception on impartiality and fairness of the tax system; penalties; personal financial constraint; changes on current government policies; and referral group such as friends, relatives).

Furthermore, Hai and See (2011) and Clotfelter, 1983 found that the high tax rate results in high tax noncompliance.

Much has been said and written on tax compliance, tax education and the dangers of evading tax. But a core determinant of tax compliance (which every government craves for) is tax awareness. High awareness by the society would encourage people to fulfill their obligations to register as taxpayer. Reporting and paying taxes properly are forms of national and civic responsibility. Most citizens do not have much understanding of what tax laws mean and why the tax system is structured and administered as it is (Braithwaite, 2007). Developing a tool to understand the level of awareness that exist among a particular population will help inform strategies for creating awareness and tax education. This is a gap identified in literature.

\section{Methodology}

The study adopted a descriptive survey approach using a cross-sectional design. This simply meant that data was gathered largely at different locations and across ages and various demographic characteristics. The Nigerian adult population of age 18 and above was the target for the study. The study utilized the non-probability sampling technique, specifically the purposive, convenience and accidental sampling techniques. The purposive technique was employed because of the age criteria, while the convenience and accidental techniques were 
employed to cut across various strata of Nigerians in the six geopolitical zones. Other criteria for inclusion in the study was that each prospective respondent was required to be able to read and write the English Language and should be willing to volunteer his or her time to complete the questionnaire.

The principal researcher employed the services of trained research assistants to help administer the questionnaire in the six major geo-political zones. Their job was to meet prospective participants in these zones and ask them to volunteer their time to complete the questionnaire. In addition, questionnaires were also distributed to each state offices of the Federal Inland Revenue Service (FIRS). This was for distribution to customers and visitors who met the research criteria. The procedure was that the informed consent of each prospective was obtained followed by the request and instructions on how to fill out the questionnaire.

A Total of 1030 participants duly completed the questionnaire and less than $4 \%$ of the cases contained missing data. This comprised of Male $=629(60.4 \%)$ and Female $=400(38.4 \%)$ and remaining $1.2 \%$ were participant that did not indicate whether they were male or female. The mean age was 33.81 and median=32.00 but the age with the highest frequency was 28 . The coverage of the questionnaire administered in the various geo-political zones in Nigeria were; North East $=56(5.4 \%)$, North West $=55(5.3 \%)$, North Central $=240(23.3 \%)$, South East $=207$ $(20.1 \%)$, South West $=318(30.9)$ and South-South $=138(13.4 \%)$. The remaining $1.6 \%$ of the sample did not indicate their geo-political zones. In this sample, $913(88.6 \%)$ of the total participants had graduate or equivalent academic qualification and the remaining percentage (11.4\%) were people ranging from no formal education to secondary qualifications or equivalent. The nature of the sample in terms of vocation included; Unemployed $=15$ $(4.4 \%)$, Students $=67(6.5 \%)$, Business/Entrepreneur $=256(24.9 \%)$, Private sector workers $=474(46.1 \%)$, Civil servants $=169(16.4 \%)$, and others $=4(.4 \%) .45$ participants or $4.4 \%$ did not indicate the nature of their vocation.

Also, $746(72.4 \%)$ participants indicated that they were tax payers and $174(16.9 \%)$ indicated that they were not tax payers. The remaining percentage did not give any indication on whether they were tax payers or not.

\subsection{Research Instrument}

The questionnaire items in this study was developed based on various inputs from tax experts and related disciplines. Thereafter a panel of tax experts confirmed the face and content validity of the questionnaire items for the research before proceeding to the exploratory analytical stage of the study.

The questionnaire was tagged Tax Aware Index (TAI) at that stage. The TAI questionnaire consisted of 11 major sections. These were the sections for Demographic information, General tax obligations, Value added tax, Income tax, Non-Profit organization, Offences and penalties, Mode of payment, Petroleum profit tax, Capital gains tax, Stamp duties and Education tax. The questionnaire initially consisted of a total of 88 items ranging from 3 items to 26 items for each of the various components. The response format was the Likert format. The scale was 5 point scale with options ranging from 1-Strongly disagree, 3-Not sure, ... 5-Strongly agree. Cronbach's alpha coefficient analysis to test for the reliability of the arious components ranged from $\alpha=0.61$ to $\alpha=0.89$. This meant that the questionnaire items for the various components ranged from fair to excellent.

\section{Results}

Using varimax rotation, a principal component analysis (PCA) was run with the ten factors in the initial factor analysis. The Tax Awareness Index (TAI) included factors include General Tax Obligations (GT), Value Added tax (VA), Income Tax (IN), Non-Profit Organisation (NP), Offences \& Penalty (OP), Mode of Payment (MP), Petroleum Profit Tax (PP), Capital Gains Tax (CG), Stamp Duty (SD) and Education Tax(ED). These ten factors of had a total of ninety-four (94) questionnaire items. As a precondition for the factor analysis, the sample size appropriateness was tested. The Kaiser Meyer Olkin measure of sampling adequacy in SPSS 18.0 was $=.89$. This was an indication that the sample size was excellent. The initial solution with the unrotated (Varimax rotation) with Eigenvalues greater one indicated a 10-factor solution (See table 1). The scree plot is capture in figure 1 . Based on the scree plot, the 10 factor solution indicated in table 1 was difference in the sense that there were likely less than 10 factors in the solution. Furthermore, the rotated factor solution for 10 factors did not show meaningful pattern. See table 2 This meant that due to the inconsistency between the initial 10 factor solution and the scree plot, more analysis was need to determine the factor structure of the Tax awareness Index. 
Table 1. Output of the variance of initial 94 items of tax awareness index

\begin{tabular}{|c|c|c|c|c|c|c|c|}
\hline \multirow[t]{2}{*}{ Items } & \multicolumn{3}{|c|}{ Initial Eigenvalues } & \multicolumn{4}{|c|}{ Extraction Sums of Squared Loadings } \\
\hline & Total & $\%$ of Variance & Cumulative \% & Total & $\%$ of Variance & Cumulative \% & Total \\
\hline 1 & 14.890 & 15.841 & 15.841 & 14.890 & 15.841 & 15.841 & 7.974 \\
\hline 2 & 5.921 & 6.299 & 22.139 & 5.921 & 6.299 & 22.139 & 6.621 \\
\hline 3 & 3.525 & 3.750 & 25.889 & 3.525 & 3.750 & 25.889 & 5.169 \\
\hline 4 & 2.954 & 3.143 & 29.032 & 2.954 & 3.143 & 29.032 & 3.339 \\
\hline 5 & 2.306 & 2.453 & 31.485 & 2.306 & 2.453 & 31.485 & 3.241 \\
\hline 6 & 2.007 & 2.136 & 33.620 & 2.007 & 2.136 & 33.620 & 3.177 \\
\hline 7 & 1.975 & 2.101 & 35.721 & 1.975 & 2.101 & 35.721 & 3.015 \\
\hline 8 & 1.808 & 1.924 & 37.645 & 1.808 & 1.924 & 37.645 & 2.234 \\
\hline 9 & 1.629 & 1.733 & 39.378 & 1.629 & 1.733 & 39.378 & 1.931 \\
\hline 10 & 1.583 & 1.684 & 41.062 & 1.583 & 1.684 & 41.062 & 1.897 \\
\hline 11 & 1.555 & 1.654 & 42.716 & & & & \\
\hline 12 & 1.438 & 1.529 & 44.245 & & & & \\
\hline 13 & 1.393 & 1.482 & 45.728 & & & & \\
\hline 14 & 1.335 & 1.420 & 47.148 & & & & \\
\hline 15 & 1.261 & 1.342 & 48.490 & & & & \\
\hline 16 & 1.216 & 1.294 & 49.784 & & & & \\
\hline 17 & 1.193 & 1.270 & 51.054 & & & & \\
\hline 18 & 1.165 & 1.239 & 52.293 & & & & \\
\hline 19 & 1.152 & 1.225 & 53.518 & & & & \\
\hline 20 & 1.145 & 1.218 & 54.736 & & & & \\
\hline 21 & 1.080 & 1.149 & 55.885 & & & & \\
\hline 22 & 1.076 & 1.144 & 57.030 & & & & \\
\hline 23 & 1.048 & 1.115 & 58.145 & & & & \\
\hline 24 & 1.035 & 1.101 & 59.246 & & & & \\
\hline 25 & 1.006 & 1.070 & 60.316 & & & & \\
\hline 26 & .973 & 1.035 & 61.351 & & & & \\
\hline 27 & .969 & 1.030 & 62.382 & & & & \\
\hline 28 & .942 & 1.002 & 63.384 & & & & \\
\hline 29 & .939 & .999 & 64.384 & & & & \\
\hline 30 & .906 & .964 & 65.348 & & & & \\
\hline 31 & .904 & .962 & 66.310 & & & & \\
\hline 32 & .877 & .933 & 67.243 & & & & \\
\hline 33 & .862 & .917 & 68.159 & & & & \\
\hline 34 & .856 & .911 & 69.070 & & & & \\
\hline 35 & .841 & .894 & 69.965 & & & & \\
\hline 36 & .821 & .874 & 70.839 & & & & \\
\hline 37 & .817 & .869 & 71.708 & & & & \\
\hline 38 & .803 & .855 & 72.562 & & & & \\
\hline 39 & .777 & .826 & 73.389 & & & & \\
\hline 40 & .771 & .820 & 74.209 & & & & \\
\hline 41 & .753 & .801 & 75.009 & & & & \\
\hline 42 & .752 & .800 & 75.810 & & & & \\
\hline 43 & .738 & .785 & 76.595 & & & & \\
\hline 44 & .726 & .772 & 77.367 & & & & \\
\hline 45 & .703 & .748 & 78.115 & & & & \\
\hline 46 & .689 & .733 & 78.847 & & & & \\
\hline 47 & .672 & .715 & 79.562 & & & & \\
\hline 48 & .672 & .715 & 80.277 & & & & \\
\hline 49 & .658 & .700 & 80.977 & & & & \\
\hline 50 & .637 & .678 & 81.654 & & & & \\
\hline 51 & .626 & .666 & 82.320 & & & & \\
\hline 52 & .616 & .655 & 82.976 & & & & \\
\hline 53 & .607 & .645 & 83.621 & & & & \\
\hline
\end{tabular}




\begin{tabular}{|c|c|c|c|}
\hline 54 & .604 & .642 & 84.263 \\
\hline 55 & .576 & .612 & 84.876 \\
\hline 56 & .574 & .611 & 85.487 \\
\hline 57 & .561 & .597 & 86.084 \\
\hline 58 & .540 & .574 & 86.658 \\
\hline 59 & .535 & .569 & 87.227 \\
\hline 60 & .529 & .563 & 87.790 \\
\hline 61 & .518 & .551 & 88.341 \\
\hline 62 & .503 & .535 & 88.876 \\
\hline 63 & .486 & .517 & 89.394 \\
\hline 64 & .472 & .502 & 89.896 \\
\hline 65 & .461 & .491 & 90.387 \\
\hline 66 & .445 & .473 & 90.860 \\
\hline 67 & .438 & .466 & 91.326 \\
\hline 68 & .429 & .456 & 91.783 \\
\hline 69 & .424 & .451 & 92.234 \\
\hline 70 & .422 & .449 & 92.683 \\
\hline 71 & .402 & .428 & 93.110 \\
\hline 72 & .399 & .425 & 93.535 \\
\hline 73 & .383 & .407 & 93.942 \\
\hline 74 & .376 & .400 & 94.342 \\
\hline 75 & .362 & .385 & 94.727 \\
\hline 76 & .349 & .371 & 95.097 \\
\hline 77 & .337 & .359 & 95.456 \\
\hline 78 & .328 & .349 & 95.805 \\
\hline 79 & .321 & .341 & 96.146 \\
\hline 80 & .308 & .328 & 96.474 \\
\hline 81 & .296 & .314 & 96.788 \\
\hline 82 & .283 & .301 & 97.090 \\
\hline 83 & .283 & .301 & 97.391 \\
\hline 84 & .269 & .287 & 97.677 \\
\hline 85 & .258 & .275 & 97.952 \\
\hline 86 & .257 & .273 & 98.225 \\
\hline 87 & .248 & .264 & 98.489 \\
\hline 88 & .237 & .252 & 98.741 \\
\hline 89 & .235 & .250 & 98.991 \\
\hline 90 & .225 & .239 & 99.230 \\
\hline 91 & .206 & .219 & 99.449 \\
\hline 92 & .200 & .213 & 99.662 \\
\hline 93 & .163 & .174 & 99.835 \\
\hline 94 & .155 & .165 & 100.000 \\
\hline
\end{tabular}




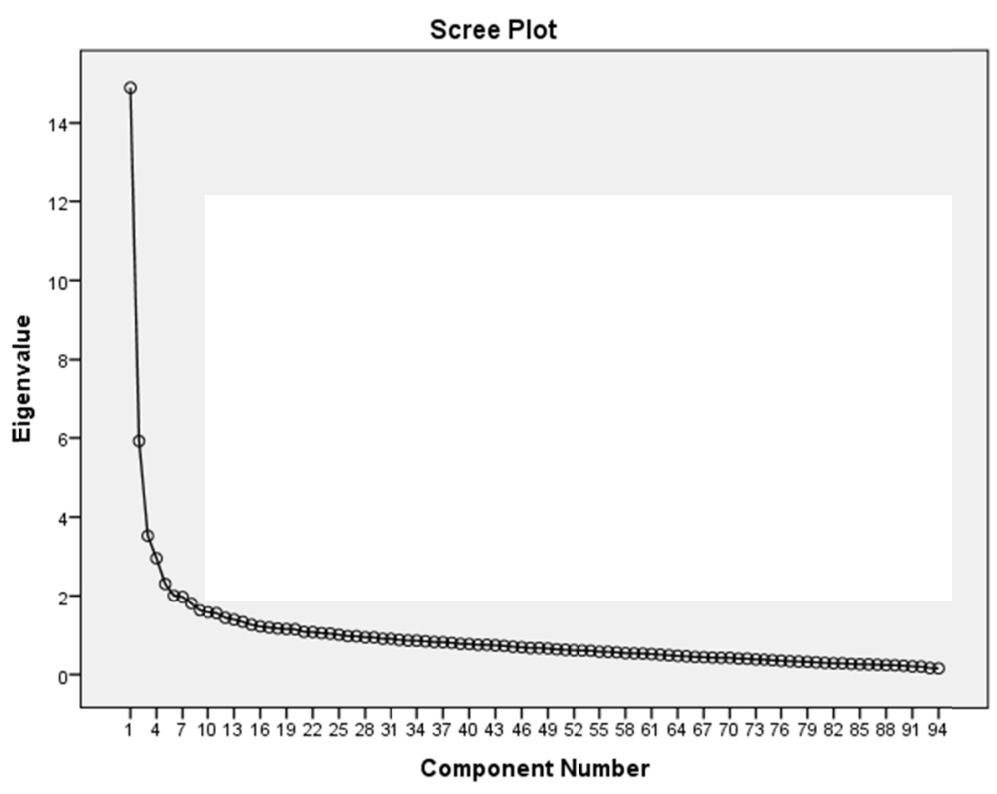

Figure 1. Scree plot of 94 tax awareness index items

Table 2. Rotated component matrix of 94 items of tax awareness index

Component

$\begin{array}{llllllllll}1 & 2 & 3 & 4 & 5 & 6 & 7 & 8 & 9 & 10\end{array}$

Every income earner should pay tax (GT1)

.43

Tax payment is an obligation every citizen must comply with (GT2)

Tax payment is a method by which Governments obtain money from citizens (GT3)

Tax Avoidance is the same thing as tax evasion(GT4)

I Should not pay taxes if I do not want to (R) (GT5)

Taxes must be paid on the profit earned by businesses (GT6)

Tax has no benefit to the country ( R) (GT7)

Tax is a reliable source of revenue in any country(GT8)

Taxes are different from levies. (GT9)

The government does not need my taxes to function (GT10)

Taxes collected by Government are misappropriated (GT11)

I will pay taxes if I can see the evidence of its utilization (GT12)

Taxes/levies paid by individuals/firms currently are too much(GT13)

Taxes are used to develop a country's amenities (GT14)

Tax payment in Nigeria does not portray good governance as it is not used for the benefit of citizens (R) (GT15)

Tax is used to redistribute income(GT16)

Taxes provide governments with steady funding required to finance infrastructure and to cater for citizens' welfare. (GT17)

The higher your income, the higher your tax (GT18)

Toll-gate fee is not tax ( R) (GT19)

The Federal Inland Revenue Service (FIRS) is the only body statutorily responsible for collection of federal taxes (GT20) 
Any State government can impose tax on its residents (GT21)

There is no difference between federal tax laws and state tax laws ( R) (GT22)

The Pay as You Earn (PAYE) is a separate type of tax payment (GT23)

The Pay as You Earn is a means through which taxes are paid (GT24)

Only businesses that occupy office space pay taxes (GT25)

Salary income and all other income are liable to $\operatorname{tax}(\mathrm{GT} 26)$

VAT is a type of indirect tax (VA1)

VAT rate in Nigeria is 5\% (VA2)

It is compulsory for all businesses in Nigeria to register for VAT(VA3)

It is compulsory for ALL businesses in Nigeria to file VAT return monthly? (VA4)

.60

Filing for VAT is the 21 st day of the month following the month of the transaction(VA5)

VAT is supposed to be included in receipts of items purchased(VA6)

VAT is paid on food each time you eat in a registered restaurant? (VA7)

VAT is borne by the final consumer(VA8)

Non-collection of VAT attracts penalty of $150 \%$ of uncollected VAT and interest at $5 \%$ above the CBN rediscount rate(VA10)

VAT is payable on rent(VA11)

Small and medium businesses pay tax if they earn income (IN1)

The law provides for income tax waivers/concessions in Nigeria (IN2)

Taxes on salaries are deducted at source (IN3)

Business must pay tax on their profit (IN4)

Company income tax rate is $30 \%$ (IN5)

Anyone who earns income should pay taxes regardless of age (IN6)

Personal income tax is to be paid only by those in paid employment (IN7)

As a business man, I have to pay my taxes (IN8)

Artisans do not pay income tax (IN9)

An employer must deduct my income tax and remit on my behalf to government(IN10)

Only house owners pay property taxes (NP1)

Non-profit organizations are required to register for tax purposes in Nigeria (NP2)

Non-profit organizations pay companies income tax if they engage in trade or business. (NP3)

I am aware NGOs deduct Income Tax from their workers' salaries? (NP4)

Churches, mosques and other places of worship are required to pay taxes in Nigeria. (NP5)

Tenement rates on property are charged and paid at the local government council(NP7)

Non-disclosure of correct income when filing tax return is a tax offense (OP1)

Failure to keep proper accounting records by a company is not an offense (OP2)

Out rightly refusing to pay taxes is against the law (OP3) 
Understating any income for tax returns is a punishable offense (OP8)

State taxes can be ignored if you pay Federal taxes(OP9)

Over/under invoicing of goods and services is not an offence (R) (OP10)

Claim of Fictitious expenses and assets by individuals and companies is against the tax laws(OP11)

Non-remittance of Value-Added Tax (VAT) is not an offence(OP12)

Non-registration for taxes is an offence(OP13)

Non invoicing of VAT is an offense (OP14)

Non - filing of VAT returns is an offense. (OP15)

A taxpayer can use FIRS electronic payment options to pay taxes (MP1)

Are you aware of Integrated Tax Administration System (ITAS)? (MP2)

A taxpayer can file returns and pay taxes on the ITAS platform? (MP3)

A taxpayer can claim refund from FIRS when tax is over paid to FIRS(MP4)

Assessment under the Petroleum Profits Tax Act is on a current year basis? (PP1)

The profits of gas producing companies, companies engaged in marketing of refined products and oil servicing companies are subject to petroleum profits taxation (PP2)

Transfer of interest in real estate triggers payment of Capital Gains Tax if the consideration for the transfer ${ }_{.55}$ is higher than the historical cost (CG1)

Only State governments administer Capital Gains Tax (CG2)

Gains arising from the disposal of an individual's principal private residence are exempted from the 43 provisions of the Capital Gains Tax Act (CG3)

CGT rate is $10 \%(\mathrm{CG} 4)$

There is loss relief for disposal of a chargeable as asset less than the historical cost (CG5)

Gains accruing to any Local Government Council is not chargeable to CGT(CG6)

Gains from disposal of Nigerian government securities, stocks and shares are not chargeable gains (CG7) .64

CGT is charged on any capital gains, accruing to any person on disposal of assets, after allowing certain .74 deductions (CG8)

CGT is assessed on a current year basis (CG9)

The Stamp Duties Act provides for the application of a duty of $1.5 \%$ on transfer of property (SD1) $\quad .57$

FIRS demands for payment of applicable duty on ALL transactions (SD2) .63

State Governments do not impose and collect stamp duties (SD3) $\quad .43$

Appeal against a Stamp Duties Commissioner's adjudication is to the High Court (SD4) .62

Unstamped documents are not acceptable as evidence in court? (SD5)

The administrative head of a Stamp Duty officer is the Commissioner of Stamp Duties (SD6) .67

Companies not registered in Nigeria, otherwise known as foreign companies are not covered by the Tertiary ${ }_{.53}$

Education Tax Act and so are not liable to the $2 \%$ tax imposed. (ED1)

Do you know that education tax is $2 \%$ of assessable profit of companies? (ED2)

Do you know that the Tertiary Education Tax collected by FIRS is remitted to Tertiary Education Tax Fund 65 (TETFUND)? (ED3)

Note. Extraction Method: Principal Component Analysis. Rotation Method: Varimax with Kaiser Normalization 10 Components/factors Extracted. Note: Loading below.4 suppressed. GT=General Tax Obligations; VA= Value Added Tax; IN=Income Tax; NP=Non-Profit Organization; OP=Offences \& Penalties; MP=Mode of Payment; PP=Petroleum Profit Tax; CG=Capital Gains Tax; SD=Stamp Duties; \& $\mathrm{ED}=$ Education Tax. 
After a series of exploratory analysis to find the most suitable factor structure that makes substantive sense, It was discovered that only a 5-factor solution showed potential for the Tax Awareness Index. See Table 3. The highlighted score in the table are the indications of the factor loading and structure. However, due to the cross loading, there may be need for further review before further test.

Table 3. Rotated component matrix of 5 factors of tax awareness index

\begin{tabular}{|c|c|c|c|}
\hline & \multicolumn{3}{|c|}{ Component } \\
\hline & 12 & 32 & \\
\hline Every income earner should pay tax (GT1) & & .44 & \\
\hline Tax payment is an obligation every citizen must comply with (GT2) & & .58 & \\
\hline Tax payment is a method by which Governments obtain money from citizens (GT3) & & .47 & \\
\hline Taxes must be paid on the profit earned by businesses (GT6) & & .49 & \\
\hline Taxes are used to develop a country's amenities (GT14) & & .49 & \\
\hline Tax is used to redistribute income (GT16) & & .43 & \\
\hline Taxes provide governments with steady funding required to finance infrastructure and to cater for citizens' welfare. (GT17) & & .54 & \\
\hline The higher your income, the higher your tax (GT18) & & .55 & \\
\hline The Federal Inland Revenue Service (FIRS) is the only body statutorily responsible for collection of federal taxes (GT20) & & .49 & \\
\hline Any state government can impose tax on its residents (GT21) & & .46 & \\
\hline The Pay as You Earn is a means through which taxes are paid (GT24) & & .51 & \\
\hline Salary income and all other income are liable to tax(GT26) & & .47 & \\
\hline VAT is a type of indirect tax (VA1) & & .45 & \\
\hline VAT rate in Nigeria is $5 \%$ (VA2) & & .62 & \\
\hline It is compulsory for all businesses in Nigeria to register for VAT (VA3) & & .59 & \\
\hline It is compulsory for ALL businesses in Nigeria to file VAT return monthly? (VA4) & & .56 & \\
\hline Filing for VAT is the 21st day of the month following the month of the transaction (VA 5) & & 60 & \\
\hline VAT is supposed to be included in receipts of items purchased (VA6) & & 68 & \\
\hline VAT is paid on food each time you eat in a registered restaurant? (VA7) & & 56 & \\
\hline VAT is borne by the final consumer (VA8) & & 74 & \\
\hline A taxpayer can apply for refund of excess VAT paid (VA9) & & 61 & \\
\hline $\begin{array}{l}\text { Non-collection of VAT attracts penalty of } 150 \% \text { of uncollected VAT and interest at } 5 \% \text { above the CBN rediscount rate } \\
\text { (VA10) }\end{array}$ & & 48 & \\
\hline Small and medium businesses pay tax if they earn income (IN1) & & 63 & \\
\hline The law provides for income tax waivers/concessions in Nigeria (IN2) & & 58 & \\
\hline Taxes on salaries are deducted at source (IN3) & & 67 & \\
\hline As a business man, I have to pay my taxes (IN8) & & & .50 \\
\hline Churches, mosques and other places of worship are required to pay taxes in Nigeria (NP5) & & & .41 \\
\hline Estate Agents and Property valuers of buildings are required to pay taxes on their commission/income (NP6) & & & .42 \\
\hline Non-disclosure of correct income when filing tax return is a tax offense ((OP1) & & & .59 \\
\hline Failure to keep proper accounting records by a company is not an offense (OP2) & & & .67 \\
\hline Out rightly refusing to pay taxes is against the law (OP3) & & & .62 \\
\hline Omitting to disclose income received in Nigeria is not an offence (OP4) & & & .554 \\
\hline Non declaration of income brought into Nigeria from sources outside Nigeria is not an offence (OP5) & & & .56 \\
\hline Giving any incorrect information in relation to any income related matter is an offence (OP6) & & & 56 \\
\hline
\end{tabular}


\begin{tabular}{ll}
\hline Failure to render returns and present documents on demand by FIRS is an offence (OP7) & $\mathbf{. 7 1}$
\end{tabular}

$\begin{array}{lc}\text { Understating any income for tax returns is a punishable offense (OP8) } & \mathbf{. 6 7}\end{array}$

State taxes can be ignored if you pay Federal taxes (OP9)

Non-remittance of Value-Added Tax (VAT) is not an offence (OP12)

Non-registration for taxes is an offence (OP13) $\quad .40 \quad .42$

Non invoicing of VAT is an offense (OP14)

$\begin{array}{ll}\text { Non - filing of VAT returns is an offense. (OP15) } & .47\end{array}$

A taxpayer can use FIRS electronic payment options to pay taxes (MP1) .41

Are you aware of Integrated Tax Administration System (ITAS)? (MP2)

A taxpayer can file returns and pay taxes on the ITAS platform? (MP3)

Assessment under the Petroleum Profits Tax Act is on a current year basis? (PP1) $\quad .50$

The profits of gas producing companies, companies engaged in marketing of refined products and oil servicing companies are subject to petroleum profits taxation (PP2)

PPT is paid in twelve installments plus the thirteenth installment which is the final settlement. (PP3)

Transfer of interest in real estate triggers payment of Capital Gains Tax if the consideration for the transfer is higher than the historical cost (CG1)

Only State governments administer Capital Gains Tax (CG2)

Gains arising from the disposal of an individual's principal private residence are exempted from the provisions of the Capital ${ }_{4}$

Gains Tax Act (CG3)

CGT rate is $10 \%(\mathrm{CG} 4)$

There is loss relief for disposal of a chargeable as asset less than the historical cost (CG5)

Gains accruing to any Local Government Council is not chargeable to CGT (CG6)

Gains from disposal of Nigerian government securities, stocks and shares are not chargeable gains (CG7) $\quad .58$

CGT is charged on any capital gains, accruing to any person on disposal of assets, after allowing certain deductions (CG8) $\mathbf{. 7 1}$

$\begin{array}{lc}\text { CGT is assessed on a current year basis (CG9) } & \mathbf{. 6 7}\end{array}$

The Stamp Duties Act provides for the application of a duty of $1.5 \%$ on transfer of property (SD1)

FIRS demands for payment of applicable duty on ALL transactions (SD2) $\quad .70$

State Governments do not impose and collect stamp duties (SD3)

Appeal against a Stamp Duties Commissioner's adjudication is to the High Court (SD4) $\mathbf{. 6 7}$

$\begin{array}{ll}\text { Unstamped documents are not acceptable as evidence in court? (SD5) } & \mathbf{. 6 5}\end{array}$

The administrative head of a Stamp Duty officer is the Commissioner of Stamp Duties (SD6)

Companies not registered in Nigeria, otherwise known as foreign companies are not covered by the Tertiary Education Tax Act and so are not liable to the $2 \%$ tax imposed. (ED1)

Do you know that education tax is $2 \%$ of assessable profit of companies? (ED2)

Do you know that the Tertiary Education Tax collected by FIRS is remitted to Tertiary Education Tax Fund (TETFUND)? (ED3)

Note. Extraction Method: Principal Component Analysis. Rotation Method: Varimax with Kaiser Normalization 5 Components/factors Extracted. Note: Loading below.4 suppressed. GT=General Tax Obligations; VA= Value Added Tax; IN=Income Tax; NP=Non-Profit Organization; $\mathrm{OP}=\mathrm{Offences} \&$ Penalties; $\mathrm{MP}=$ Mode of Payment; $\mathrm{PP}=$ Petroleum Profit Tax; $\mathrm{CG}=$ Capital Gains Tax; $\mathrm{SD}=\mathrm{Stamp}$ Duties; \& $\mathrm{ED}=$ Education Tax.

\section{Discussion}

The aim of this study was to develop a Tax Awareness Index. The study hypothesized an initial 10 factor solution based on inputs from tax experts and available literature. The 10 factor solution had a total of 94 sample items. However, the 10-factor solution did not provide meaningful outcome as initially hypothesized in varimax 
rotation. Subsequently, a series of exploratory analysis was conducted to understand a more enduring structure of the factor solution produced mixed results because there were a lot of cross loadings. These cross loading were early signs of systematic errors either due to the nature of the questionnaire or the structure of questionnaire.

In situations like these, one way or another, the researcher has to find ways of establishing what makes sense by looking through the factor loadings and making appropriate decision on what is most plausible in interpreting the outcome of the factor solution. For example, in this study, mode of payment (MP), stamp duties (SD), education tax (ED) capital gains tax (CG) and petroleum profit tax (PP) all loaded as one factor. Does this mean that all these components are more or less the same in content and construct? The answer could be yes or no. What needs to be examined is to understand if all these components have a connection in one way or another.

If that is the case, they can all be collapsed and classified as one factor Nevertheless, based on the PCA, a five factor model depicting a probable indication of a Tax Awareness Index was revealed. Factor one consisted mainly of some questionnaire items of General Tax Obligations (GT), factor two consisted of some factors Value Added Tax (VA), factor three consisted of some questionnaire items of Income Tax (IN) and Non-Profit Organization.

Factor four consisted of questionnaire item of Offences \& Penalties (OP) and factor five comprised some questionnaire items from mode of payment (MP), Petroleum Profit Tax (PP), Capital Gains Tax (CG), Stamp Duties (SD) and Education Tax (ED). The five factors emerging from the factor analysis are valid with respect to measuring tax awareness among Nigeriañs.

\section{Conclusion}

The main objective of this study was to develop a Tax Awareness Index for use in the Nigerian context. The study found out that the initial 10 -factor solution proposed did not make substantive sense. Rather it was found that a 5-factor structure of Tax Awareness Index was most plausible in the given circumstance. The next stage of this process will require that we review the factors in terms of content and construct and rename some of them in a confirmatory factor analysis (CFA).

Best practices require that different samples should be used for both the exploratory and confirmatory stages of the research. For now it will suffice to suggest we should now move from the exploratory stage to the confirmatory stage. Therefore, a major limitation of this study is that the 5-factor structure proposed in this study cannot be said to be final, but it offers us the prospects of getting a true structure of a Tax Awareness Index. That can be achieved in a follow up study to the present one.

\section{References}

Adefeko, A. (2018). A More Robust Approach to Boosting Nigeria's Tax Revenue. Leadership, 3.

Adekanola, O. (1997). Efficient Tax Collection and Effective Tax Administration in Nigeria. Paper presented at a ii seminar organized by the University of Lagos Consultancy Services Otta, 15 May: 25-35

Adeosun, K. (2017). VAIDS: FG has recruited 2,190 tax officers. The Nation Newspapers.

Akinfala, F. (2017). Impact of New Tax Regime on Revenue Collection. Paper presented at the Federal Account Allocation Committee (FAAC) Retreat, Uyo, Akwa Ibom State. August, 2017.

Alstadsæter, A. (2013). The Effect of Awareness and Incentives on Tax Evasion. CESifo Working Paper Series, 4369(42).

Amina, A.,\& Saniya, K. (2015). Tax compliance and its determinant the case of Jimma Zone, Ethiopia. International Journal of Research in Social Sciences, 6(2).

Berhane, Z. (2011). The Influence of Tax Education on Tax Compliance Attitude. Unpublished Ph.D. Thesis, Department of Accounting and Finance, Addis Ababa University Ethiopia.

Beza, M. (2014). Determinants of Tax Payer's Voluntary Compliance with Taxation in East Gojjam, Ethiopia. Research journal of Business and economics, 3(9).

Braithwaite, V. (2007) Taxation and Good Governance. University House Lecture and House Dinner Series, Australian National University, Canberra. Retrieved from http://www.vab.anu.edu.au/present/taxunihouse.pdf

Clotfelter, C. T. (1983). Tax evasion and tax rates: An analysis of individual returns. Review of Economics and Statistics, 65(3), 363-373.

FMF. (2017). National Tax Policy. Federal Ministry of Finance, Abuja, Nigeria.

Fowler, T.(2018). Tax Initiatives being undertaken by FIRS and the focus for 2018. Paper Presented At the 
Nigeria Economic Outlook 2018.January, 2018. Lagos.

Hai, O. T., \& See, L. M. (2011). Intention of Tax Non-Compliance-Examine the Gaps. International Journal of Business and Social Science, 2(7), 79-83.

Hastuti, R. (2014). Tax Awareness and Tax Education: A Perception of Potential Taxpayers"International. Journal of Business, Economics and Law, 5(1).

Lemessa, T. (2007). Determinants of Taxpayers' Voluntary Compliance with Taxation: the casenstudy of Dire Dawa City.

Mukhlis, I., Utomo, S. H., \& Soesetio,Y. (2015). The Role of Taxation Education on Taxation Knowle dge and Its Effecton Tax Fairness as well as Tax Compliance on Handicraft SMEs Sector sin Indonesia" International Journal of Financial Research, 6(4).

Ola, C. S. (2001). Income Tax Law and practice in Nigeria. Ibadan: Heinemann Educational Books (Nigeria) Limited.

Osinbajo, Y. (2017). Voluntary Assets and Income Declaration Scheme (VAIDS), the Nation Newspapers. June 29.

Palil, M. R. (2010). Tax knowledge and tax compliance determinants in self-assessment system in Malaysia. Unpublished Ph.D. thesis, University of Birmingham.

Rahayu, et al. (2017). The role of taxpayer awareness, tax regulation and understanding in taxpayer compliance. Journal of Accounting and Taxation, 9(10), 139-146.

Santi, A. (2012). Analysis of Effect of Taxation Awareness, Rational Attitudes, Environment, Penalties Sanctions, and Tax Authorities Attitudes on Taxpayer Compliance. Research Journal of Finance and Accounting.

Savitiri, E., \& Musfialdy, T. (2016). The Effect of Taxpayer Awareness Tax Socialization Tax Penalties Compliance Cost at Taxpayer Compliance with Service Quality as Mediating Variable. Procedia - Social and Behavioral Sciences, 219, 682-687.

Steinmo, S. (1996). Taxation and Democracy: Swedish, British, and American Approaches to Financing the Modern State. Yale University Press.

\section{Copyrights}

Copyright for this article is retained by the author(s), with first publication rights granted to the journal.

This is an open-access article distributed under the terms and conditions of the Creative Commons Attribution license (http://creativecommons.org/licenses/by/4.0/). 